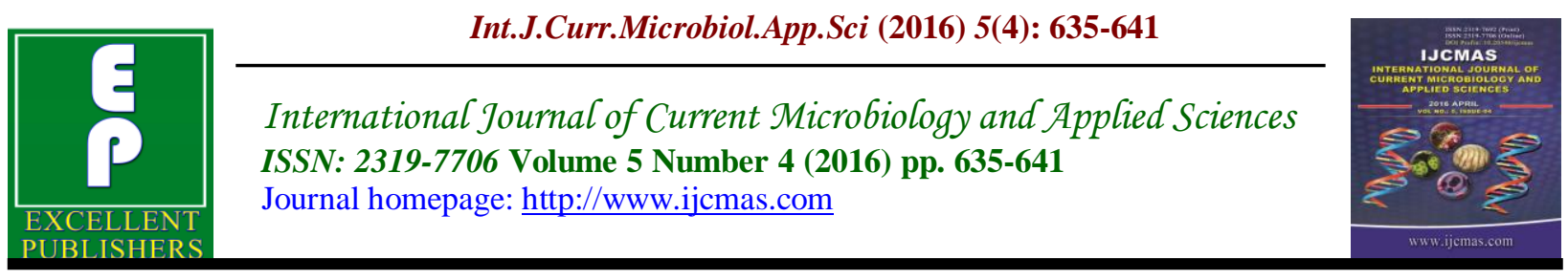

Original Research Article

http://dx.doi.org/10.20546/ijcmas.2016.504.072

\title{
Antioxidant Activity of Leaf Extracts from Zygophyllum coccineum L. Collected from Desert and Coastal Habitats of Egypt
}

\author{
El-Shora, H M*, El-Amier, Y. A. and Awad, M.H \\ Botany Department, Faculty of Science, Mansoura University, Egypt \\ *Corresponding author
}

\begin{abstract}
A B S T R A C T
Keywords

Zygophyllum coccineum $\mathrm{L}$. Antioxidant Activity, Desert and Coastal Habitats

\section{Article Info}

Accepted:

22 March 2016

Available Online:

10 April 2016

Zygophyllum coccineum L. (Family: Zygophyllaceae) was collected from coastal and desert habitats from Egypt. The plant leaves from each habitat were collected and used in preparation of the various extracts in hexane, methylene chloride, ethyl acetate and butanol.ZCD leaf extracts exhibited higher scavenging activity than $\mathrm{ZCC}$ in the four extracts. The antioxidant activity was measured using $\operatorname{DPPH}(2,2$ ' diphenyl-1-picrylhydrazyl) test. Butanol fraction exhibited the highest scavenging activity. The antioxidant activity measured in every extract was dependent on the concentration of the extract. Various compounds were obtained by GC/MS and they were identified. 1-nonadecene, 9-octadecenoic acid, 2-methyl propanoic acid, $\beta$-sitosteol, tricosane and tetracosane were found in leaves of coastal plant (ZCC) and absent from the desert plant (ZCD). Stigmast-5-en-3-ol was found in leaves of the desert plant and not detected from the coastal plant. Docosene, 1-eicosanol, hexacosane, heptacosane, nonacosane, 6-Ethyl-5-hydroxy-2,3,7-trimethoxynaphtho quinone and pentacosane were found in the leaves of $Z$. coccineum from both habitats under investigation.
\end{abstract}

\section{Introduction}

Species of genus Zygophyllum represent a group of succulent plants that are salt tolerant and/or drought resistant. $Z$. coccineum is a small perennial herb with succulent leaves and somewhat whitish flowers of saline and sandy habitats near the sea. The growth and distribution of Zygophyllum are dependent on the soil chemical structure of its habitats (Hammoda et al., 2013, Yaser et al., 2015).

Plant primary metabolism produces products that enhance the growth and development of plants, howeverthey are not required for the plant to survive. This primary metabolism composed of chemical reactions which allow the plant to live. Secondary metabolism plays a pinnacle role in keeping all the of plants' systems working properly. Secondary metabolism facilitates the primary metabolism in plants (El-Shora et al., 2015a).

It has been reported that secondary metabolites play important role in protection of plants from salt stress, UV light and other physical stress. Secondary metabolites utilized for engage pollinators as well as 
seed dispersers, as signals (Wink, 2008).

Z. coccineum has been reported in previous studies as medicinal plant (Batanouny et al., 1999, El-Shora et al., 2016a). The leaves, fruits and stems are used in folk medicine as a drug active against gout, rheumatism, asthma, and hypertension. The plant is also used as a diuretic, antihistaminic, local anesthetic and antidiabetic agent(Osman and Badawy (2014).

Higher plants are the main source of medicine throughout the human history. Many plant species are still used for the traditional as well as modern symptoms of medicine since they contain several active compounds. These active compounds are normally extracted from the various plant parts (Shon et al., 2003).

Some of the secondary metabolites are known by their antioxidant activity that can retard, or prevent oxidation processes. They react with free radicals, acting as oxygen scavengers, react with chelating metals and donate hydrogen atoms to the free radical (Kitazuru et al., 2004, El-Shora et al., 2015b).

There is an increasing interest in antioxidants, particularly in those intended to prevent the presumed deleterious effects of free radicals in the human body, and to prevent the deterioration of fats and other constituents of foodstuffs. In both cases, there is a preference for antioxidants from natural rather than from synthetic sources (Abdallaand Roozen, 1999).

Antioxidant compounds have been used in prevention of oxidative degradation, in cosmetology and dermopharmacy (Belguidoum et al., 2015). The synthetic antioxidants including BHT (butylated hydroxytoluene) and BHA and have been used widely in industry butit has been reported to have toxicological effect s(butylated hydroxyanisole).

The aim of the present investigation was to determine the antioxidant activity of various extracts and the chemical components of Zygophyllum coccineum from desert and coastal habitats.

\section{Materials and Methods}

\section{Plant Materials}

Zygophyllum coccineum L. was collected from naturally growing population in coastal (Deltaic Mediterranean coast) and inland desert (WadiHagul) of Egypt. The plant was identified by Prof. NaserBarakat, Professor of Plant Ecology, Botany Department, Minia University, Egypt.

\section{Preparation of Leaf Powder of $Z$. coccineum}

Z.coccineum leaves from the coastal plant (ZCC) and from the desert plant (ZCD)were handily cleaned, washed several times with distilled water to remove dust and other residues. The leaves were then dried at room temperature for several days till complete dryness. After drying the leaves were ground into powder and then preserved in well stopped bottles.

\section{Processing of the Plant Material}

The dried leaves of Z.coccineum were extracted by separating funnel with nhexane followed by methylene chloride, ethylacetate and then butanol to give the corresponding extracts which were used for determination of antioxidant activity.

\section{Determination of Antioxidant Activity}

DPPH $\quad(2,2-$ diphenyl-1-picrylhydrazyl $)$ free radical scavenging activity of the 
various prepared extracts from $Z$. coccineum leaves was determined following the method of Bozinet al.(2006).

Freshly prepared $(0.004 \% \mathrm{w} / \mathrm{v})$ methanol solution of DPPH radical was prepared and stored at $10 \mathrm{C}$ in the dark. A methanol solution of the test compound was prepared. A $10 \mu 1$ aliquot of the methanol solution was added to $3 \mathrm{ml}$ of DPPH solution. Absorbance measurements were recorded immediately with a UV-visible spectrophotometer at $515 \mathrm{~nm}$.

$\%$ Radical scavenging activity $=[1-$ $\left(\mathrm{A}_{\text {sample }} / \mathrm{A}\right.$ control $\left.)\right] \times 100$, where $\mathrm{A}$ is the absorbance at $515 \mathrm{~nm}$.

\section{GC/MS Analysis of Hexane Extract}

A sample of hexane extract ofZ. Coccineum leaves from both locations were analyzed by GC/MS. The resulting compounds were identified by comparing their mass spectra with those of their analogous by NIST library (Adams, 1995). The identification of phytochemical compounds is based on the peak area (which representsthe percentage of that compound), molecular weight and molecular formula.

\section{Results and Discussion}

DPPH is a test used widely as free radical to evaluate the reducing substances (Cotelle et al., 1996). It is a reagent used for estimation of the free radical scavenging activity of various plant extracts (Duan et al., 2006).

\section{Antioxidant Activity of the Various Extracts}

The antioxidant activity of the various extracts including hexane, methylene chloride, ethyl acetate and butanol was determined by DDPH. It is apparent from the results that ZCD leaves exhibited higher scavenging activity than $\mathrm{ZCC}$ in all extracts as well as in the control as shown in Table 1. Also, butanol fraction exhibited the highest scavenging activity.

\section{Antioxidant Activity of Hexane Extract}

The antioxidant activity of hexane fraction was measured at various concentrations 100 , 200, 400, 600, 800 and $1000 \mathrm{ppm}$. The results are shown in (Table 2). It is apparent that the scavenging activity of hexane extract was higher in ZCD leaves compared with ZCC.

\section{Antioxidant Activity of Methylene Chloride Extract}

The antioxidant activity of methylene chloride fraction was measured at different concentrations 100, 200, 400, 600, 800 and $1000 \mathrm{ppm}$. The results are shown in Table 3 . It is evident that the scavenging activity was higher in ZCD leaf extract of methylene chloride compared with ZCC and in both cases it was dependent on the extract concentration.

\section{Antioxidant Activity of Ethyl Acetate Extract}

The antioxidant activity of ethyl acetate fraction was measured at different concentrations 100, 200, 400, 600, 800 and $1000 \mathrm{ppm}$. The results are shown in Table 4. It is clear that the scavenging activity was higher in ZCD leaves compared with that of ZCC and it was dependent on the concentration.

\section{Antioxidant Activity of Butanol Extract}

The antioxidant activity of butanol extract was measured at different concentrations 10 , 20, 40, 60, 80 and $100 \mathrm{ppm}$ for the ZCD and $200,400,600,800$ and 1000ppm. The results are shown in Table 5 andshow that for ZCD expressed higher activity than ZCC. 
Table.1 DPPH Antioxidant Scavenging Activity of the Selected Fractions

\begin{tabular}{|r|c|c|}
\hline Solvent & $\begin{array}{c}\text { \% Scavenging of } \\
\text { ZCC extract }\end{array}$ & $\begin{array}{c}\text { \% Scavenging } \\
\text { ZCD extract }\end{array}$ \\
\hline Control & $1.67 \pm 0.05$ & $1.73 \pm 0.04$ \\
\hline Hexane & $8.88 \pm 0.2$ & $10.80 \pm 0.3$ \\
\hline Methylene chloride & $13.26 \pm 0.4$ & $21.91 \pm 0.6$ \\
\hline Ethyl acetate & $23.13 \pm 0.3$ & $27.60 \pm 0.5$ \\
\hline Butanol & $28.45 \pm 0.5$ & $76.24 \pm 0.9$ \\
\hline
\end{tabular}

Table.2 DPPH Antioxidant Scavenging Activity of Hexane Fraction

\begin{tabular}{|c|c|c|}
\hline $\begin{array}{c}\text { Concentration } \\
(\mathrm{ppm})\end{array}$ & $\begin{array}{c}\text { \%Scavenging of ZCC } \\
\text { extract }\end{array}$ & $\begin{array}{c}\text { \%Scavenging of ZCD } \\
\text { extract }\end{array}$ \\
\hline 100 & $4.5 \pm 0.1$ & $4.6 \pm 0.3$ \\
\hline 200 & $5.5 \pm 0.2$ & $6.5 \pm 0.2$ \\
\hline 400 & $6.5 \pm 0.4$ & $7.7 \pm 0.4$ \\
\hline 600 & $9.5 \pm 0.3$ & $10.3 \pm 0.5$ \\
\hline 800 & $13.7 \pm 0.5$ & $14.2 \pm 0.6$ \\
\hline 1000 & $17.1 \pm 0.3$ & $19.4 \pm 0.3$ \\
\hline
\end{tabular}

Table.3 DPPH Antioxidant Scavenging Activity of Methylene Chloride Fraction

\begin{tabular}{|c|c|c|}
\hline $\begin{array}{c}\text { Concentration } \\
(\mathrm{ppm})\end{array}$ & $\begin{array}{c}\text { \% Scavenging of ZCC } \\
\text { extract }\end{array}$ & $\begin{array}{c}\text { \% Scavenging of ZCD } \\
\text { extract }\end{array}$ \\
\hline 100 & $5.8 \pm 0.2$ & $12.1 \pm 0.4$ \\
\hline 200 & $7.1 \pm 0.2$ & $20.4 \pm 0.5$ \\
\hline 400 & $10.4 \pm 0.3$ & $21.6 \pm 0.3$ \\
\hline 600 & $13.2 \pm 0.6$ & $22.6 \pm 0.5$ \\
\hline 800 & $17.1 \pm 0.4$ & $24.7 \pm 0.6$ \\
\hline 1000 & $19.0 \pm 0.5$ & $26.1 \pm 0.3$ \\
\hline
\end{tabular}

Table.4 DPPH Antioxidant Scavenging Activity of Ethyl Acetate Fraction

\begin{tabular}{|c|c|c|}
\hline $\begin{array}{c}\text { Concentration } \\
(\mathrm{ppm})\end{array}$ & $\begin{array}{c}\text { \% Scavenging of ZCC } \\
\text { extract }\end{array}$ & $\begin{array}{c}\text { \% Scavenging of ZCD } \\
\text { extract }\end{array}$ \\
\hline 100 & $1.4 \pm 0.06$ & $5.6 \pm 0.2$ \\
\hline 200 & $31.5 \pm 0.5$ & $32.2 \pm 0.4$ \\
\hline 400 & $33.0 \pm 0.4$ & $34.8 \pm 0.3$ \\
\hline 600 & $33.9 \pm 0.7$ & $40.7 \pm 0.7$ \\
\hline 800 & $37.5 \pm 0.5$ & $43.3 \pm 0.9$ \\
\hline 1000 & $37.5 \pm 0.8$ & $49.3 \pm 0.7$ \\
\hline
\end{tabular}


Table.5 DPPH Antioxidant Scavenging Activity of Butanol Fraction

\begin{tabular}{|c|c|c|}
\hline \multirow{4}{*}{} & $\begin{array}{c}\text { Concentration } \\
(\mathrm{ppm})\end{array}$ & \% Scavenging activity \\
\cline { 2 - 3 } & 10 & $07.6 \pm 0.2$ \\
\cline { 2 - 3 } ZCD & 20 & $21.8 \pm 0.4$ \\
\cline { 2 - 3 } extract & 40 & $23.2 \pm 0.6$ \\
\cline { 2 - 3 } & 60 & $24.7 \pm 0.6$ \\
\cline { 2 - 3 } & 80 & $27.6 \pm 0.5$ \\
\hline \multirow{4}{*}{ ZCC } & 100 & $29.2 \pm 0.4$ \\
\cline { 2 - 3 } extract & 100 & $05.7 \pm 0.2$ \\
\cline { 2 - 3 } & 200 & $22.7 \pm 0.4$ \\
\cline { 2 - 3 } & 400 & $26.3 \pm 0.5$ \\
\cline { 2 - 3 } & 600 & $39.8 \pm 0.7$ \\
\hline
\end{tabular}

Table.6 MS Data of Compounds Identified by GC/MS Analysis

\begin{tabular}{|l|l|}
\hline \multicolumn{2}{|l}{ The phytochemical compounds } \\
\hline Compounds in ZCC only & MW \\
\hline 1-nonadecene & 268 \\
\hline 9-Octadecenoic acid & 282 \\
\hline 2-methyl propanoic acid & 350 \\
\hline Stigmasterol & 412 \\
\hline$\beta$-sitosteol & 414 \\
\hline Tricosane & 324 \\
\hline Tetracosane & 338 \\
\hline Compounds in ZCC and ZCD & MW \\
\hline Docosene & 308 \\
\hline 1-Eicosanol & 298 \\
\hline Hexacosane & 366 \\
\hline Heptacosane & 380 \\
\hline Nonacosane & 408 \\
\hline $\begin{array}{l}\text { 6-Ethyl-5-hydroxy-2,3,7- } \\
\text { trimethoxynaphtho quinone }\end{array}$ & 292 \\
\hline Pentacosane & 352 \\
\hline Compounds in ZCDonly & MW \\
\hline Stigmast-5-en-3-ol & 414 \\
\hline
\end{tabular}

Thus, the present results showed antioxidant activity in all various extracts. In support, previous studies on $Z$. coccineum reported antioxidant and antimicrobial activities as showed in literature survey (Gibbons and Oriowo, 2001). 


\section{Chemical Analysis}

Sample from $n$-hexane extract of $Z$. coccinum leaves from costal and desert habitats were analyzed by GC/MS technique, which resulted in identification of several compounds (Table 5).These compounds were identified by comparing their mass spectra with those of their analogous reported by NIST library (Admas, 1995).

It was observed that stigmast-5-en-3-ol is present in leaves of desert Z. coccineum and absent from the coastal one (Table 6). However, there are 7 compounds present in leaves of the coastal plant but absent from the desert plant. They were tricosane, tetracosane, 1-nonadecene, 9-octadecenoic acid, $\beta$-sitosteol and stigmasterol.

As general, phytochemicals include two main groups according to their functions in the plant : primary and secondary metabolites. The primary metabolites are amino acids, proteins, sugars and chlorophyll whereas the secondary metabolites consist of alkaloids, tannins, saponins, flavonoids, terpenoids, and phenolic compounds (Krishnaiah et al., 2007). Z. coccineum exhibited appreciable amounts of saponins, flavonoids, alkaloids and total phenol (El-Shora et al., 2016b).

Higher content of flavonoids as secondary metabolites was found in the crude extractand butanol fraction of $Z$. album(ElGhoulet al., 2011; Belguidoum et al., 2015). Flavonoids are well known as antioxidants and are compounds of low molecular weight, involving fifteen carbon atoms and organized in a C6-C3-C6 configuration. The structure consists of two aromatic rings, $\mathrm{A}$ and $\mathrm{B}$, connected by a 3-carbon bridge, usually in the form of a heterocyclic ring, $\mathrm{C}$ (Merken and Beecher, 2000).
Thus, it seems likely from the results that the antioxidant activity of $Z$. coccineum leaf extracts may be due to the various bioactive compounds detected in the plant leaves.

In conclusion, the present results showed that the various extracts of $\mathrm{Z}$. coccinum obtained from the leaves exhibited an antioxidant activity particularly those of the desert plant. This proves that $Z$. coccinum can be used as natural source for antioxidant instead of the synthetic antioxidants which are carcinogenic and harmful to mankind.

\section{References}

Adams, R. P. (1995). Identification of essential oil components by gas chromatography/mass spectrometry. Carol Stream, II: Allured Publishing Corporation.

Abdalla, A.E. and Roozen, J.P. (1999). Effect of plant extracts on the oxidative stability of sunfloweroil and emulsion, Food Chem., 64: 323-329.

Belguidoum, M., Dendougui, H. and Kendour, Z. (2015). In vitro antioxidant properties and phenolic contents of Zygophyllum album L. from Algeria. J. Chem. Pharmac. Res., 7(1): 510-514.

Bozin, B., Mimica-Dukie, N., Simin, N.and Anackov, G. (2006).Characterization of the volatile composition ofessential oil of some lamiaceae species and theantimicrobial and antioxidant activities of the entireoils. J Agri. Food Chem. 54: 1822-1828.

Cottele, N., Benniez, J., Catteau J., Pommery, J., Wallet, J. and Gaydou, E. (1996). Antioxidant properties of hydroxyl flavanes. Free Rad. Biol. Med. 20: 3543.

Duan, X., Zhang, W., Li, X. and Wang, B. (2006). Evaluation of antioxidant property of extract and fractions obtained from red alga, Polysiphoniaurceolata. Food Chem. 95: 37-43. 
El-Amier, Y.A, El-Shora, H.M. and Awad, M.H. (2016). Ecological study on Zygophyllum coccineum L. in coastal and inland Desert of Egypt.J.Agric. Ecol. Res. Inter., 6(4): 1-17.

El-Ghoul, J., Smiri, M., Ghrab, S., Boughattas, N. and Ben-Attia, M. (2011), Antihyperglycemic, antihyperlipidemic and antioxidant activities of traditional aqueous extract of Zygophyllum album in streptozotocin diabetic mice. doi:10.1016/j.pathophys.2011.12.001

El-Shora, H., El-Farrash, A., Kamal, H. and Abdel razek, A. (2015a). Enhancement of antioxidant defense system by UVradiation in Fenugreek as a medicinal plant. Int. J. Adv. Res. 5: 529-535.

El-Shora, H., El-Farrash, A., Kamal, H. and Abdel razek, A. (2015b). Positive role of UV radiation in enhancing secondary metabolite production in Fenugreek leaves. Int. J. Adv. Res. 3: 536 - 543.

El-Shora, H.M., El-Amir, Y.A. and Awad, M. H. (2016a).Antimicrobial activity and allelopathic potential of Zygophyllum coccineum L. on Chenopodium album L.British Appl. Sci. Technol.(In Press).

El-Shora, H.M., El-Amir, Y.A. and Awad, M. H. (2016b). Comparative phytochemical studies on Zygophyllum coccineumL. from different habitats, Egypt.British. Appl. Sci. Technol.(In Press).

Gibbons, S. and Oriowo, M.A. (2001). Antihypertensive effect of an aqueous extract of Zygophyllum coccineum L. in rats. Phytoth. Res. 15:452-455 DOI: 10.1002/ptr.836.
Hammoda, H.M., Ghazy, N.M., Harraz, F.M., Radwan, M.M., ElSohly, M.A. and Abdallah, I.I. (2013). Chemical constituents from Tribulusterrestris and screening of their antioxidant activity.Phytochem. 92: 153-159.

Kitazuru E. R., Moreira A. V. B. and Villavicencio A. L. (2004). Effects of irradiation on natural antioxidants of cinnamon (Cinnamomum zeylanicum N.) 71(1):39-41.

Krishnaiah, D.R. andSarbatly, U. and Bono. A. (2007). Photochemical and antioxidants for health and medicine. A move toward nature. Mol. Boil. Rev., 1: 97.

Merken, H.M. and Beecher G.R, (2000). Measurement of food flavonoids by high-performance liquid chromatography: A review. J Agric Food Chem., 48(3):577-99.

Osman, H.E. and Badawy, R. K. (2014). Effect of pollution on the chemical content and secondary metabolites of Zygophyllum coccineum and Tamarixnilotica. Egyptian Pharm. J., 12: 73-82.

Shon, M., Kim, T. and Sung, N. (2003). Antioxidants and free radical scavenging activity of Phellinus baumii extracts. Food Chem. 82: 593-597.

Wink, M. (2008): Evolutionary advantage and molecular modes of action of multicomponent mixtures used in phytomedicine. Curr. Drug Metab. 9: 996-1009.

\section{How to cite this article:}

El-Shora, H M, Alamir, Y. A. and Awad, M.H. 2016. Antioxidant Activity of Leaf Extracts from Zygophyllum coccineum L. Collected from Desert and Coastal Habitats of Egypt Int.J.Curr.Microbiol.App.Sci. 5(4): 635-641. doi: http://dx.doi.org/10.20546/ijcmas.2016.504.072 